\title{
Eucalyptus worker
}

\author{
Tim PSP2M Uniqbu
}

\begin{abstract}
Social capital in the community in Waplau village, Buru District grows and develops along with the achievement of fulfilling the necessities of life. Cooperation relationship in oil refining activities of eucalyptus leaves are awakened among land owners, tenants, rental workers and lids so that the social capital is established with participation, trust, cooperation and mutual relations and become a constantly preserved norm. This research is conducted based on the preference of the implementation of Eucalyptus oil refining process in Waplau village as an effort to benefit and fulfill household needs. The research location is focused in Waplau village with the consideration of the number of the more dominant eucalyptus oil workers compared to its municipal village in Buru Regency, research samples are landlords of eucalyptus trees, land tenants, rental laborers, and Dealer. Research using primary data obtained from observations and interviews directly with the informant. The method of data analysis used to follow the concept presented by Miles and Huberman and Spradley. The results showed that social capital became an indicator of the success of eucalyptus oil workers in achieving the objectives. Aspects of social capital has a strong relationship with the existence of landowners, tenants and rental workers, as well as working groups between children, leaf sequencer, cooks and laborers in completing oil refining tasks so that social capital Able to be an instrument for the productivity of eucalyptus oil in Waplau village.
\end{abstract}

Keywords: social capital, eucalyptus oil, worker, waplau

\section{INTRODUCTION}

The white wood plants (Melaleuca Cajuputi Sub sp cajuputi) in Indonesia spread naturally, especially in the island of Java and Maluku by utilizing the leaves to be distilled traditionally by the public or commercially into essential oils High economic value. White wood plants are suitable in dry areas because it can produce oil with higher quality and weight compared to areas where the soil is rather wet[1]. However, eucalyptus trees have excellent adaptability, so they can grow in wet areas and swamp areas. Buru Island is one of the major islands in Maluku province, the archipelago of the islands that also have the Banda Islands, the Kei Islands, and the Aru Islands. The area of this island is about 9,505 km, wider than the island of Bali which is about 5,636 square kilometres[2]. The island consists of two districts namely Buru and South Buru.

Social capital has become very important in the sustainability of a group or individual's life in the rural areas of Buru regency, because it is part of the social Energy for its community[3]. This social capital is a role in tying the interaction between landowners, tenants and eucalyptus Oil workers, bridging between social groups in a community of eucalyptus oil workers or even suppliers and landowners and able to establish Extensive cooperation with existing stakeholders[4]. Each community has the resources and potential of social capital that are accessible and utilized by its members. A community or community is a potential social capital, where the community or community gives awareness and limits to citizens, including contributing to the needs and interests of the common[5].

The power of social capital can be known through elements that are embedded in the social structure of the community [6]. Some elements of social capital include Trust (trust), reciprocal values and norms, institutions and associations, mutual relations and networking. The implementation of social capital power is understood in three typologically namely social capital as an adhesive for community residents, as connectors and as connections or access.

Fukuyama states that social capital plays a very important role in enabling and strengthening the lives of modern society. Social capital is not only the company's assets but also serves to help grow the company's business[7]. Many companies have indirectly used social capital in carrying out their companies, either from inside or outside the company. Thus, in order for the company to grow then the issue of how to maintain and increase social capital. According to Lawang, the network discussed in social capital indicates a relationship in people or groups that allows the supervisor of the problem to run efficiently and effectively. The essence of all this essentially refers to the social principle of working together is easier to address the problem than on selfemployed.

Social capital as a fundamental capital for the community can effectively streamline capital and other potentials, but inherent elements benefit and can be attached to all community residents and do not contradict the standards of applicable values Universal[8].

Khoirrini in his studies on the influence of human capital and social capital to performance stated that other knowledge and structural dimensions affect the human capital and social capital. Capital and social capital have positive and significant effect on performance[9]. In addition, Imam Malik in his research on the social capital of Clove farmer in support of clove plantation farming in Banyumas District raises farmers utilizing social capital that they have in several ways, namely: utilizing Network to enhance the farming ability of clove farmer, to distribute the harvest, utilize the value and norms as a control in the farm business clove, and make the trust as the basis in the spread of agriculture Clove[10]

The study of eucalyptus Oil workers became important due to several factors including[11]; Availability The increasingly limited number of workforce, the sustainability of the business is fragmented on weak economic strata. Therefore, this research becomes a gateway or opening road to strategize the implementation of sustainable eucalyptus Oil refining business in Buru 
Island.

\section{Literature REVIEW}

\subsection{Eucalyptus Oil Workers}

Agroindustri Eucalyptus Oil as one form of small household industry that processes white wood leaves into eucalyptus oil, has a role in enhancing the value added and increase the income and absorb manpower[12]. Therefore, to date, the agro industrial of eucalyptus oil is growing rapidly in some areas in Indonesia, one of them in the Buru regency. With market opportunities getting better and expanding, not all eucalyptus oil companies are able to deal with it[13].

Based on information from the Ministry of Industry and Trade in Buru district, said that before the monetary crisis of 1997, the number of oil agro industrial enterprises is very much, this condition has a good impact on the economy of Buru Island. However, this has changed since the occurrence of the monetary crisis, resulting in economic turmoil so that many of the white wood oil agro industrial companies shut down and switch to other businesses[14]. For companies that still survive needed a strategy to face the market competition.

\subsection{Employee's Living System}

Agroindustri Eucalyptus Oil as one form of small household industry that processes white wood leaves into Eucalyptus Oil, has a role in enhancing the value added and increase the income and absorb manpower. Therefore, to date, the Affryzal of eucalyptus oil is growing rapidly in some areas in Indonesia, one of them in the Buru regency[15]. With market opportunities getting better and expanding, not all eucalyptus oil companies are able to deal with it.

Based on information from the Ministry of Industry and Trade in Buru district, said that before the monetary crisis of 1997[16], the number of oil Affryzal enterprises is very much, this condition has a good impact on the economy of Buru Island. However, this has changed since the occurrence of the monetary crisis, resulting in economic turmoil so that many of the white wood oil affryzal companies shut down and switch to other businesses[17]. For companies that still survive needed a strategy to face the market competition.

\section{METHOD}

The research was conducted in Waplau village in Waplau District, Buru Regency. The determination of the research site is purposive (intentionally). Waplau Village was chosen as the location of the research because the percentage of high-quality eucalyptus oil workers were compared to other villages in Buru Regency. The number of informant that will be interviewed as many as 25 people taken purposive in consideration of respondents are considered as parties related to the research objectives[18]. The informant is a landowner, land tenant, rental worker and refiner or oil refining buyer in Waplau village.

In the interview step researchers conducted a thorough interview with the related parties as well as provided a questionnaire to the informant at the location in response to the implementation of the white wood refining work of other supporting factors[19]. Researchers are also looking for complementary information related to the social capital found in white wood oil workers through the Internet as well as library studies by using Government Documents/archives related to the production of eucalyptus oil in Waplau village. .

The analytical techniques used in this study are the analysis of qualitative data following the concepts expressed by Miles and Huberman and Spradley[20]. Miles and Huberman, suggests that activities in the analysis of qualitative data are conducted interactively and ongoing continuously at every stage of the research so that it is complete, and the data is until saturated. Activity in data analysis is data reduction[21], data presentation (data display), draw conclusion or verification[22].

This research is conducted based on the preference of the implementation of Eucalyptus oil refining process in Waplau village as an effort to fulfill the needs of households and efforts to obtain the Advantages. In addition, the research aims to obtain a primary picture of the work process as well as a pattern of social relations that awakens between landowners, tenants, rental laborers and liders in the social capital frame in Waplau village.

\section{RESULt}

The existence of eucalyptus trees in Waplau village is a blessing for most of the surrounding population, by taking the leaves and burning it, the resulting oil can be a major source of income for the family[23]. Since the expansion of the region, the population density in Waplau village is increasing, one of the main causes is Waplau village has been used as the capital of the district and the development of education and health infrastructure so that it attracts most The surrounding population to settle around the village.

The increasing population of Waplau village, in fact, is not followed by the increase in the number of eucalyptus workers. Percentage of white wood workers to the population in which the year 2015 white timber workers have a high percentage, in subsequent years the apparent reduction in the number of workers so that in the year 2018 percentage Leaving only 6.40 percent of the total population. In addition to plantation in Dusun Krai Bandungharjo Village, in 1987 successfully built a distillery, with the existence of the factory able to empower workers and communities around Dusun Krai so that the profession as a worker Eucalyptus oil is still preserved to date[24]. 
Network patterns where there is a symmetrical relationship between landowners, tenants, rental laborers and liders. Between owner and tenant, the belief arises from agreement and contract of Employment agreed so that the basis of the agreement is the basis of trust for land owners and tenants[25][26]. For tenants and labour, the basic cooperation relationship is based on the belief that most tenants do not work but give full confidence for the refining process done by rental worker consisting of 4-7 people in one Group. Meanwhile, the dealer are part of the working network in Waplau Village but do not have a direct relationship in the distillation process, the workers have a relationship in the process of distribution and marketing of oil refining.

The social capital that woke up to the division of work duties of children, cooks, leaf sequencer and rental laborers is the capital that continues to change. Thus the dynamism of eucalyptus oil workers in carrying out refining activities is not detached from the social capital that awakens to the life of eucalyptus oil workers. Social capital is essentially a series of values and norms that are a tangible manifestation of a dynamic institution[27]. The real manifestation of social capital in eucalyptus Oil workers is demonstrated in the form of trust, social networking, responsibility and cooperation.

The division of work duties to each worker resulted in each person involved in the distillation process will have an interrelated activity with each other. In its execution, if one worker does not fulfill its obligations it will be a burden for others who are together in one working group, then the elements of reciprocation, belief, value system and norms, tolerance, will be Indicator that will be a social capital in the activities of eucalyptus oil workers.

\section{Discussion}

There are several indicators of the reduction of eucalyptus oil workers among others; The availability of new land outside the refining of eucalyptus oil, working orientation due to increasing levels of education and the use of machinery in the refining process so that landowners or tenants are no longer working on distillation but only Collect leaves for sale to the owners of modern distillation tools. This condition is the cause of the reduction and shifting of the number of eucalyptus oil workers in Waplau village.

With the reduced number of workers, the condition will also affect the amount of eucalyptus oil production from year to year [24]. In producing eucalyptus oil there are several elements of interrelated society including land owners, land tenants, rental workers and liers (buyers of eucalyptus Oil). Each section has different functions and powers and is closely related to one another. Tenants have the dependency of the owner to get the distillery's permit in the area of land owners, as well as rental workers who have a dependency to wear their energy in the refining process, the pattern of the working network that awakens.

The social capital found in society grows and develops with human development[28]. Similarly, the social capital contained in eucalyptus oil workers, for that matter to be understood about the pattern of cooperation that prioritizes the trust between workers with landowners and tenants without suspected of fraud made By one of the groups. In such a context social capital has an important role[29]. The social capital of eucalyptus Oil workers is the asset, value and effort based on the interests, the similarity of environmental conditions (social, economic, resources) which also determines the development of the activity of workers and lease laborers [30].

In the refining process of eucalyptus oil, rental laborers are the most important part where the process of taking the leaves until the distillation is conducted in groups and each member of the group is given duties and responsibilities. These duties and responsibilities are given with consideration of the work experience.

Circulatory activities of eucalyptus oil workers as long as they are in the distillation site. The description works without a formal, but understood by each individual in the working Group of Eucalyptus Oil. The author tries to construct that the social capital owned by Eucalyptus Oil workers is a force that can be used to stimulate collective action. The collective actions that are present are utilized to respond to situations within a group which are then developed into individual adaptability to the habits or traditions that have existed within the Working Group they follow.

Explained by Hanifan the social capital is not a capital in the ordinary sense such as wealth or money, but it is more metaphorically, i.e. real assets or capital that is important in community life. Social capital which contains trust, reciprocal exchange, social norms, and ethical values, is the foundation of the Penompang that will determine the development and sustainability of various business activities in different sectors of life[31].

Understand the social capital that leads to the aspects of social organizations, such as beliefs, norms, and social networks that can facilitate collective action[32]. Social capital is emphasized on community togetherness to improve the quality of life together and to make better changes and adjustments continuously. Burt in 1992 defines social capital as the ability for people to do Associations (relate) to each other so that it becomes a very important force, not only on economic aspects, but also on every aspect of existence Other social[33].

Social capital in the form of bonding is social capital in the context of ideas, relationships, and attention-oriented (inward looking)[34]. This kind of social capital is generally emerging and is in a homogeneous society. Putnam termed Society with bonding social capital as a hallmark of the Sacred Society, a society that is dominated and survives with a totalitarian structure, hierarchical, and covered by certain dogma. Eucalyptus oil workers in Waplau village are a form of society dominated by land tenure and working capital by a group of people but not in totalitarian and certain dogma as presented by Putnam. The allocation of hierarchy and the pattern of everyday social interaction makes eucalyptus oil workers in Waplau village always guided by values and norms that are considered beneficial for all parties even more dominated by owners and tenants Property Grounds.

The author assumes that the social capital owned by Eucalyptus Oil workers is a force that can be used to stimulate collective 
action[35]. The collective actions that are present are utilized to respond to situations outside the community which are then developed into adaptability.

Hence the description of the orientation and action of eucalyptus Oil workers explains that the dimension of social capital grows within their group in it contains a series of values and norms and patterns of social interaction in regulating their activities during distillation. The main dimension of social capital lies in the ability of eucalyptus oil workers to cooperate to build a social network to achieve a common goal[36]. Essentially the ability of the worker to establish and build life together depends heavily on the condition of the willingness of all workers to find values and norms, which will make all subject to the collective interest.

\section{Conclusion}

With the system of cooperation in the refining of eucalyptus oil makes groups of people to benefit and fulfill the needs of life. The rental and recruitment systems of distillation workers, making landowners, tenants, rental laborers and liders interact well so that there is a mutual trust and relationship that can strengthen the cooperative relationship that will They created. The trust that grows from land owners and land tenants to workers makes the opportunity to meet the needs of households can be carried out. The social capital that formed in the environment of eucalyptus Oil workers is a social capital that grows from active participation, trust, cooperation and mutual relations.

\section{REFERENCES}

[1] M. C. B. Umanailo, “Kalesang Dorp in Context De Bouw van Village,” 2019, pp. 1-7.

[2] M. C. B. Umanailo, Ilmu Sosial Budaya DasaR, 1st ed. Namlea: FAM PUBLISHING, 2015.

[3] A. Wael et al., "' Bupolo' Motion Reading," Int. J. Sci. Technol. Res., vol. 8, no. 9, pp. 2154-2158, 2019.

[4] M. C. B. Umanailo, “Desa Sebagai Poros Pembangunan Daerah,” 2015.

[5] B. Sam et al., "Female Feminism in the Customary Island of Buru," Int. J. Sci. Technol. Res., vol. 8, no. 8, pp. 18771880, 2019.

[6] M. C. B. Umanailo et al., “Comprehension To Village,” 2018, pp. 1-2.

[7] A. L. Wabula, M. Musyawir, A. Irmawati, B. Rebel, D. M. Darajat, and M. C. B. Umanailo, "Maghrib Movement," Int. J. Sci. Technol. Res., vol. 8, no. 9, pp. 2134-2138, 2019.

[8] M. C. B. Umanailo, Masyarakat Buru Dalam Perspektif Kontemporer, vol. 53, no. 9. 2015.

[9] L. J. Buton et al., "The Effect of Nasa Liquid Organic Fertilizer Concentration and Planting Distance to Growth and Production of Beans," Int. J. Sci. Technol. Res., vol. 8, no. 9, pp. 2144-2147, 2019.

[10] M. C. B. Umanailo, “Teknik praktis grounded theory dalam penelitian kualitatif,” 2018, no. April, p. 127.

[11] M. C. B. Umanailo et al., "Cybercrime Case as Impact Development of Communication Technology That Troubling Society," Int. J. Sci. Technol. Res., vol. 8, no. 9, pp. 1224-1228, 2019.

[12] M. C. B. Umanailo, "Overview of Phenomenological Research," 2019, pp. 1-6.

[13] M. C. B. Umanailo, N. Handayani, A. Masniati, S. H. Makatita, and S. Lisaholit, "The Urbanization and Diversification of Farmland Namlea Village," Int. J. Sci. Technol. Res., vol. 8, no. 8, pp. 1049-1053, 2019.

[14] S. Yusuf, M. C. B. Umanailo, R. N. Putri, D. Qhuril, M. Ely, and D. Darma, "Village Institution Relations in the Utilization of Village Funds in Namlea District," Int. J. Sci. Technol. Res., vol. 8, no. 8, pp. 1837-1842, 2019.

[15] M. C. B. Umanailo, "Eksistensi Waranggana Dalam Ritual Tayub."

[16] S. Rachman, H. Hamiru, M. C. B. Umanailo, Y. Yulismayanti, and H. Harziko, "Semiotic Analysis of Indigenous Fashion in The Island of Buru," Int. J. Sci. Technol. Res., vol. 8, no. 8, pp. 1515-1519, 2019.

[17] B. S. Amanto, M. C. B. Umanailo, R. S. Wulandari, T. Taufik, and S. Susiati, "Local Consumption Diversification," Int. J. Sci. Technol. Res., vol. 8, no. 8, pp. 1865-1869, 2019.

[18] M. C. B. Umanailo, Sosiologi Hukum, 1st ed. Namlea: FAM PUBLISHING, 2016.

[19] M. C. B. Umanailo, "Keterbatasan penggunaan teknologi informasi pada pelayanan dan pembelajaran di universitas iqra buru," 2016.

[20] A. Hasan Afandi and M. C. B. Umanailo, "Watudakon Citizens 'Social Conflict on Joker Toll Road Development in 2017 in Kesamben District, Jombang Regency," J. Soc. Sci. Res., vol. Special Is, no. 5, pp. 656-661, 2018.

[21] M. C. B. Umanailo, " BUPOLO " Movement. 2019.

[22] S. S. F. Assagaf et al., "Construction of the Village as a Development Shaft in the Island Buru," Int. J. Sci. Technol. Res., vol. 8, no. 9, pp. 2139-2143, 2019.

[23] M. C. B. Umanailo, "Postmodernisme dalam pandangan jean francois lyotard," 2018.

[24] L. Rumkel, B. Sam, and M. C. B. Umanailo, “Village Head Partnership, Village Consultative Body and Customary Institution in Village Development," Int. J. Sci. Technol. Res., vol. 8, no. 8, pp. 1058-1063, 2019.

[25] M. C. B. Umanailo, R. Umanailo, R. Bugis, and A. T. Bon, "Empowerment Community in Buru Regency," in Proceedings of the International Conference on Industrial Engineering and Operations Management, 2019, pp. 2070-2075.

[26] M. C. B. Umanailo, "Consumption Diversification of Local Community," J. AGRISEP Kaji. Masal. Sos. Ekon. Pertan. 
dan Agribisnis, vol. 18, no. 1, pp. 61-74, Mar. 2019.

[27] M. C. B. Umanailo, I. Hamid, M. Nawawi, S. Pulhehe, S. Yusuf, and A. T. Bon, “Utilization of Qualitative Methods in Research Universities," in Proceedings of the International Conference on Industrial Engineering and Operations Management, 2019, pp. 2076-2081.

[28] M. C. B. Umanailo and T. Yatno, Kajian dan Analisis Sosiologi Dalam Bentuk Kumpulan Essay, Makalah dan Opini. 2015.

[29] M. C. B. Umanailo, "Strategi Bertahan Hidup Petani Padi Gogo di Pulau Buru," J. Ekon. Pertan. dan Agribisnis, vol. 3, no. 1, pp. 50-58, Jan. 2019.

[30] M. C. B. Umanailo, Marginalisasi Buruh Tani Akibat Alih Fungsi Lahan. 2016.

[31] M. C. B. Umanailo, "'recycling' consumerism to construction of modern society," no. 1904, 1964.

[32] M. C. B. Umanailo et al., "Dominance of Economic Capital in Political," in Community Development, Decentralization $\mathcal{E}$ Local Autonomy Politic \& Democracy, Fisip Universitas Brawijaya, 2018, pp. 1-120.

[33] M. C. B. Umanailo, Masyarakat Buru Dalam Perspektif Kontemporer (Kajian Kritis Perubahan Sosial di Kabupaten Buru), vol. 1. Namlea, 2017.

[34] R. Bugis et al., “Workers in the Namlea Market,” Int. J. Sci. Technol. Res., vol. 8, no. 9, pp. 2044-2047, 2019.

[35] M. C. B. Umanailo, M. Yulisvestra, K. K. Oki, W. Mulyasari, and R. Ridwan, "The Thought of Emile Durkheim in the Contestation of Development in Indonesia," Int. J. Sci. Technol. Res., vol. 8, no. 8, pp. 1881-1885, 2019.

[36] W. Malmia et al., "Problem-Based Learning as an Effort to Improve Student Learning Outcomes," Int. J. Sci. Technol. Res., vol. 8, no. 9, pp. 1140-1143, 2019. 